\title{
RUCH OPORU W JUGOSŁAWII \\ W OKRESIE II WOJNY ŚWIATOWEJ \\ W AUDYCJACH ROZGŁOŚNI IM. TADEUSZA KOŚCIUSZKI
}

\begin{abstract}
ADRIAN KAROLAK
Abstract. The resistance movement in Yugoslavia during the Second World War in the programmes by the Tadeusz Kościuszko Broadcasting Station.

The broadcasting station dealt with a variety of topics concerning the war and occupation. One of them was the resistance movement in Yugoslavia during the Second World War. The broadcasting station's announcements touched upon many problems, among other things, they mentioned the towns that had been liberated by the guerillas from the occupation by the Axis states. They also discussed the topic of sabotage in the railway system and the industry which worked for the military purposes of the Third Reich. The losses suffered by the enemy (in weapons, munitions, soldiers, etc.) were often announced. It was sometimes directly emphasized that behind those actions there were communists, in contrast to other guerilla groups (the Chetniks), who apparently decided to cooperate with the Fascists. The aim of those messages was to spread among the Polish society the attitudes that would result in the development of a resistance movement on a massive scale. This was mainly the duty of the young generation.

Apart from strictly military questions, it is easy to notice that the station was not indifferent towards the political events which were taking place in Yugoslavia during the Second World War. Also this time the party uniting various circles and social groups - according to the authors of the radio programmes - was the revolutionary left wing. It had a programme which would be realized after the end of the warfare. The aim of broadcasting those messages was the willingness to mobilise the Poles, who were expected to unite, to fight for freedom and independence together. The leading role in this process was to be left to the communists.
\end{abstract}

Autor: Adrian Karolak, Miejska Biblioteka Publiczna Łódź Widzew im. Lucjana Rudnickiego, ul. Bartoka 27, Łódź 92-546, adriankarolak@onet.eu

Słowa kluczowe: ruch oporu w Jugosławii, rozgłośnia im. T. Kościuszki, II wojna światowa

Keywords: the resistance movement in Yugoslavia, the Tadeusz Kościuszko Broadcasting Station, The Second World War

Balcanica Posnaniensia. Acta et studia, XXII/2, Poznań 2015, Wydawnictwo Instytutu Historii UAM, pp. 117-138, ISBN 978-83-63047-88-7, ISSN 0239-4278. Polish text with a summary in English.

Po agresji Niemiec na Związek Radziecki (22 czerwca 1941 r.) władze tego państwa dostrzegły potrzebę podjęcia intensywnych działań propagandowych. Niekorzystny początkowo dla Armii Czerwonej obrót zmagań militarnych na froncie spowodował, że mające swą siedzibę w państwie radzieckim od 1919 r. struktury Międzynarodówki Komunistycznej (MK) zostały przeniesione w październiku 1941 r. ${ }^{1}$

1 Лебедева Н.С., Наринский М.М., Коминтерн и Вторая мировая война (до 22 июня 1941 года), [w:] История Коммунистического интернационала 1919-1943, red. odp. А. О. Чубарьян, Москва 2002, s. 206-207. 
z Moskwy do Ufy i Kujbyszewa, a tylko niektóre ich ekspozytury nadal pozostały w stolicy ZSRR.

W ramach aparatu Komitetu Wykonawczego (KW) MK działał wówczas m.in. Wydział Prasy i Radiofonii, którym kierował w latach 1941-1943 Bedřich Geminder (pseudonim G. Friedrich). Po ewakuacji Kominternu z Moskwy w skład wyżej wymienionego Wydziału w końcu 1941 r. wchodziły: Agencja Telegraficzna (kierownicy Grupy Kujbyszewskiej - Fritz Glaubauf, Grupy Moskiewskiej - Friedl Fürnberg); Redakcja „Biuletynu Informacyjnego” (redaktor odpowiedzialny Aleks Kellerman²), Grupa Nasłuchu (redaktor odpowiedzialny Friedrich Heksman), Biuro Tłumaczeń (kierownik Maria Kryłowa) z czterema sekcjami - rosyjską, niemiecką, romańską i angielską, Biblioteka (kierownik Fiodor Kozłow) ${ }^{3}$.

W latach 1941-1942 działała ogólna redakcja radiowa i 16 tajnych stacji językowych (narodowych). Redakcję ogólną tworzyli pracownicy Kominternu: Palmiro Togliatti (Włoch), Klement Gottwald, Bedřich Geminder (Czesi), Friedl Fürnberg (Austriak), Mihály Farkas (Węgier). Redaktorami odpowiedzialnymi redakcji narodowych byli: Wilhelm Pieck, G. Zinner - redakcje niemieckie (były dwie); Klement Gottwald - czeska; Zofia Dzierżyńska - polska; Wasil Kołarow - bułgarska; Palmiro Togliatti - włoska; Dolores Ibarruri - hiszpańska; Matyas Rákosi - węgierska; Ana Pauker - rumuńska; Urcho Kari (nazwisko rodowe Usko Karunien) - fińska; André Marty - francuska; Vaclav Kopeckỳ - słowacka; Richard Magnusson (właściwie: Richard Gyptner) - norweska; Velimir Vlahović - serbska; Johann Koplenig - austriacka; Bruno Koehler - sudecko-niemiecka ${ }^{4}$.

W 1943 r. wymienione stacje włączono do Wydziału Prasy i Radiofonii. Składał się on z: sekcji radiofonii (redakcje: austriacka - „Austria” - red. Franz Schelling; dwie redakcje bułgarskie - im. Christo Botewa i "Głos Ludu” - red. Wyłko Czerwenkow; węgierska im. Lajosa Kossutha - red. József Révai; hiszpańska - „Wolna Hiszpania” - red. Enrique Castro; włoska - „Wolny Mediolan” - red. Piere Allard (właściwie: Giulio Ceretti), Fimien Edo (właściwie: Eduardo D’Onofrio), Anselmo Marabini; niemiecka - „Wolne Niemcy” - red. Anton Ackermann; norweska „Wolna Norwegia” - red. Georg Moltke; polska - im. Tadeusza Kościuszki - red. Zofia Dzierżyńska; rumuńska - „Wolna Rumunia” - red. Walter Roman; słowacka „Za Wolną Słowacje” - red. Stefan Reis; sudecko-niemiecka - „Niemcy Sudeccy” red. Rudolf Appelt; fińska - „Wolne Radio Narodu Fińskiego” - red. Inkeri Lehtinen; francuska - „Radio Francja” - red. Arthur Ramette (ps. Charles Dupuis); czeska „Za Wyzwolenie Narodowe” - red. Jiři Kotátko, Maria Švermowa; jugosłowiańska - „Wolna Jugosławia” - red. Albert Dravić (właściwie Đuro Salai), Piotr Lazić (właściwie Lazar Stefanović), Dragutin Đurđev, Stanislav Samarđić; sektor nasłuchu

\footnotetext{
${ }^{2}$ Aleks Kellermann używał jeszcze jednego pseudonimu Sándor Nógrádi. Właściwie nazywał się Grünbaum, niestety nie znamy jego imienia.

${ }^{3}$ Адибеков Г. М., Шахназарова Э. Н., Шириня К. К., Организационная структура Коминтерна. 1919 - 1943, Wyd. РОССПЭН, Москва 1997 , s. 221.

${ }^{4}$ Tamże, s. 224.
} 
radiowego - Friedrich Heksman; sektor informacji - Aleks Kellerman; sektor tłumaczeń - Maria Kryłowa; agencja telegraficzna - Fritz Glaubauf; biblioteka - Fiodor Kozłow. Na początku 1943 r. w Wydziale pracowało 161 osób 5 .

Po rozwiązaniu MK wiosną 1943 r. rozgłośnie radiowe podlegały tajnemu Instytutowi Naukowo-Badawczemu (INB) nr 205 (były Wydział Prasy i Radiofonii KW MK) Wydziału Informacji Międzynarodowej (WIM) KC WKP(b). Kierował nim Bedřich Geminder, a jego zastępcą był Friedl Fürnberg ${ }^{6}$.

Wyżej wymienione redakcje, podlegające Kominternowi, a następnie WIM KC WKP(b), kierowały komunikaty do krajów okupowanych przez III Rzeszę lub od niej zależnych po to, by zachęcić społeczeństwa do podejmowania walki narodowowyzwoleńczej przeciwko Niemcom, wspomagając jednocześnie państwo sowieckie w trudnym dla niego okresie klęsk militarnych.

Poza wyżej wymienionymi rozgłośniami MK powołała do życia wspomnianą już polskojęzyczną radiostację im. Tadeusza Kościuszki ${ }^{7}$. Rozpoczęła ona działalność w sierpniu 1941 r. i kontynuowała ją do 22 sierpnia 1944 r. $^{8}$, kiedy to została rozwiązana przez Sowietów, ponieważ po powstaniu Polskiego Komitetu Wyzwolenia Narodowego jej działalność była już niepotrzebna. Siedziba redakcji mieściła się początkowo w Moskwie, a po ewakuacji KW MK w październiku 1941 r. jej nowym miejscem nadawania stała się Ufa w Baszkirii. Tam również znajdowało się kierownictwo Kominternu9 ${ }^{9}$. W pracę radia zaangażowani byli polscy komuniści znajdujący się w czasie II wojny światowej na terenie ZSRR. Wśród nich wymienić należy: Juliusza Burgina, Tadeusza Daniszewskiego, Gertrudę Finderową, Zofię Dzierżyńską, Józefa Kowalskiego, Wacława Lewikowskiego, Józefa Olszewskiego, Halinę Pietrak, Stefana Wierbłowskiego, Leona Zieleńca ${ }^{10}$. Należy dodać, że wyżej wymienione osoby były od wczesnych lat swojego życia zaangażowane w ruchu komunistycznym. W związku z tym Sowieci mieli do nich zaufanie.

Wśród wielu zagadnień, podejmowanych w komunikatach przez polskojęzyczną redakcję, ważną rolę odgrywały informacje dotyczące jugosłowiańskiego ruchu oporu w okresie II wojny światowej.

\footnotetext{
5 Tamże, s. 221.

${ }^{6}$ Tamże, s. 233. Na podstawie uchwały Biura Politycznego KC WKP(b) z 13 czerwca 1943 r. powołano do życia WIM KC WKP(b) patrz: tamże, s. 232.

${ }^{7}$ R. Nazarewicz, Komintern a lewica polska. Wybrane problemy, Wyd. Instytut Wydawniczy Książka i Prasa, Warszawa 2008, s. 143.

${ }^{8}$ A. Sobór-Świderska, Jakub Berman. Biografia komunisty, Wyd. IPN, Warszawa 2009, s. 131.

9 J. Kowalski, Rozgłośnia im. Tadeusza Kościuszki (fragment wspomnienia), „Z pola walki” 1961, nr 4, s. 340-341.

10 Tamże, s. 340, 342-344.
} 
Najazd Niemców na Jugosławię rozpoczął się o świcie 6 kwietnia 1941 r. zajęciem Đerdapu, górskiego przełomu Dunaju położonego przy granicy rumuńskiej. W tym samym czasie 450 niemieckich samolotów zrzuciło bomby na centrum Belgradu, a bombowce włoskie pojawiły się nad Dalmacją. 7 kwietnia niemiecka 12 . Armia, stacjonująca w zachodniej Bułgarii nad granicą jugosłowiańską, opanowała Skopje, przecinając ważne połączenie Jugosławii z Grecją. Działania kontrofensywne podjęła armia jugosłowiańska tylko na froncie włoskim w Albanii, gdyż postęp armii niemieckich był tak szybki, że już 10 kwietnia padł Zagrzeb, a 12 kwietnia Belgrad ${ }^{11}$. Kapitulowały przed Niemcami całe armie, a w Bjelovarze i innych miastach chorwackich ustasze wzniecili powstanie, następnie zaś radośnie witali wkraczające oddziały niemieckie.

Jugosłowiańskie dowództwo naczelne 14 kwietnia podjęło decyzję o kapitulacji, następnego zaś dnia rząd z królem Piotrem opuścili kraj, udając się samolotem do Grecji, a następnie do angielskiej Palestyny. Odlatując, generał Dušan Simović powierzył misję podpisania rozejmu z Niemcami nowemu szefowi Sztabu Generalnego armii jugosłowiańskiej, generałowi Danile Kalafatoviciowi. Dnia 17 kwietnia podpisano „Postanowienie o zawarciu rozejmu”, zawierające obok warunków kapitulacji liczne punkty o charakterze politycznym. Mimo wątpliwej wartości prawnej tego aktu, który podpisali pełnomocnicy szefa sztabu, a nie rząd, „Postanowienia” ułatwiły Niemcom utworzenie w podbitej Jugosławii marionetkowych rządów. Dopiero 4 maja 1941 r., już w Londynie, rząd gen. Simovicia ogłosił kontynuowanie wojny z państwami Osi.

Podbitą Jugosławią podzieliły się zwycięskie państwa. Niemcy anektowały część terenów Słowenii. Pozostałe przypadły Włochom. Znaczne obszary Dalmacji, zachodnią Macedonię, niemal całe Kosowo i Metohiję przyłączono do włoskiej „Wielkiej Albanii”. Węgry anektowały Bačkę, Baranję, Prekomurje i Međumurje, a Bułgaria uzyskała Macedonię do Ochrydy z częścią Kosowa i skrawek wschodniej Serbii.

Z Chorwacji, przyłączonej do niej Bośni, Hercegowiny i Sremu utworzono tzw. Niezależne Państwo Chorwackie (Nezavisna Država Hrvatska - NDH), w którym władzę objęli ustasze na czele z Ante Paveliciem. Państwo to pozostawało pod protektoratem Włoch i Niemiec. Król włoski Wiktor Emanuel III przekazał koronę Chorwacji swemu krewniakowi, księciu Simone di Spoleto, który przybrał imię Tomisław II, lecz nigdy realnie tronu nie objął. Stolicą państwa została bośniacka Banja Luka ${ }^{12}$.

Okupantom udało się zorganizować w Jugosławii szeroki system kolaboracji, obejmujący nie tylko Chorwację. Pod koniec kwietnia 1941r. Niemcy utworzyli w Serbii

${ }^{11}$ L. Podhorodecki, Jugostawia. Dzieje narodów, państw i rozpad federacji, Wyd. Mada, Warszawa 2000, s. 165. O działaniach wojennych w Jugosławii pisze: W. Walkiewicz, Jugosławia. Państwa sukcesyjne, Wyd. Trio, Warszawa 2009, s. 115-116. Na temat agresji niemieckiej na państwa półwyspu bałkańskiego istnieje bardzo bogata literatura. Wymienić należy choćby: T. Rawski, Agresja niemiecka przeciwko Grecji i Jugosławii. 27.03.-5.04.1941, „Wojskowy Przegląd Historyczny” 1966, nr 1, s. 70-95; tenże, Wojna na Bałkanach, Wyd. M.O.N, Warszawa 1981; J. Kozeński, Agresja na Jugostawię 1941, Wyd. Instytut Zachodni, Poznań 1979.

12 L. Podhorodecki, dz. cyt., s. 166. M.in. o powstaniu Niezależnego Państwa Chorwackiego (NDH) pisze S. Pavlowitch, Hitler's New Disorder. The Second World War In Yugoslavia, Wyd. Oxford University Press, Londyn 2008, s. 22-27. 
tzw. rząd komisaryczny z Milanem Acimoviciem, a potem Milanem Nediciem na czele (byłym szefem sztabu i ministrem obrony Jugosławii). Otrzymał on szereg uprawnień, łącznie z prawem organizowania żandarmerii i własnych sił zbrojnych - domobrany. W południowej Słowenii Włosi rządzili przy pomocy rady z Marko Natlačenem na czele. Okupant skrzętnie wykorzystał siły faszystowskie i separatystyczne przedwojennej Jugosławii, skłaniając je do współpracy. Pomógł mu w tym znacznie kryzys prozachodnich ugrupowań politycznych, bierna postawa rządu emigracyjnego, zaniechanie wszelkiej działalności przez przywódców dawnych stronnictw mieszczańskich, wreszcie poparcie udzielone Paveliciowi przez kler katolicki.

W tej sytuacji zorganizowaną siłą antyfaszystowską, zdolną do podjęcia walki, stała się partia komunistyczna. Kierowana była wówczas przez Biuro Polityczne w składzie: Josip Broz-Tito, Milovan Đilas, Edvard Kardelj, Rade Končar, Franc Leskošek, Ivan Milutinović, Aleksander Ranković. Na początku maja 1941 r. na tajnej naradzie Komitetu Centralnego Komunistycznej Partii Jugosławii (KC KPJ) uznano, że głównym jej zadaniem powinna być walka $\mathrm{z}$ okupantem i rodzimym faszyzmem. Była to odpowiedź na politykę terroru III Rzeszy.

27 czerwca 1941 r. kierownictwo partii powołało Sztab Główny Narodowowyzwoleńczych Oddziałów Partyzanckich Jugosławii, złożony z członków Biura Politycznego z sekretarzem generalnym KC Broz-Tito na czele. W dniu 7 lipca kompania partyzancka zaatakowała patrol żandarmerii kolaborantów w miejscowości Bela Crkva pod Krupnjem w Serbii. Był to faktyczny początek powstania. Działania rozwijały się pomyślnie, toteż w końcu września wyzwolono spory teren z ośrodkiem w Užicach (ok. $120 \mathrm{~km}$ na wschód od Sarajewa). W tym mieście znalazł się niebawem cały Sztab Główny i kierownictwo partii, tu 19 października ukazał się pierwszy numer organu KC KPJ „Borba”. W tzw. Republice Užickiej powstała nawet fabryka broni, która wyprodukowała ponad 16 tys. karabinów. Funkcjonowały tu normalnie kolej, poczta i bank ${ }^{13}$.

W dniu 13 lipca 1941 roku wybuchło powstanie w Czarnogórze. Niebawem ruch wyzwoleńczy objął rejony zamieszkałe przez ludność serbską w Bośni, Hercegowinie i Chorwacji. W rezultacie na początku jesieni 1941 r. cała południowo-zachodnia Serbia, niemal cała Czarnogóra i znaczna część Bośni oraz Hercegowiny znalazły się w ręku powstańców. Na wyzwolonych terenach powstały ludowe organy władzy, tworzyły się organizacje kobiece i młodzieżowe, nowe jednostki bojowe, poczęła wychodzić prasa. 26 października postanowiono przekształcić Sztab Główny w Sztab Naczelny, natomiast narodowe kierownictwa w wojskowe (otrzymały nazwę Sztabów Głównych).

Wybuch powstania zmusił okupantów do przerzucenia znacznych sił wojskowych do Jugosławii. W listopadzie 1941 r. znajdowało się w tym kraju już 450 tys. żołnierzy niemieckich, włoskich, węgierskich, bułgarskich oraz kolaborantów. 16 października Hitler wydał rozkaz zgniecenia ruchu oporu. W niecałe dwa tygodnie później faszy-

${ }^{13}$ L. Podhorodecki, dz. cyt., s. 166, 168. Na temat Republiki Užickiej patrz: W. Walkiewicz, dz. cyt., s. $131-132$. 
ści przeszli do pierwszej, wielkiej ofensywy, trwającej od końca września do grudnia 1941 r. Główne uderzenie zostało skierowane na Republikę Užicką. Mimo poświęcenia, wobec ogromnej przewagi liczebnej i technicznej nieprzyjaciela, powstańcy musieli wycofać się z niej i odejść do Sandżaku, a częściowo do południowej Serbii.

Okupantowi nie udało się jednak zniszczyć głównych sił partyzantów, którzy pod koniec roku mieli pod bronią około 80 tys. ludzi. 22 grudnia 1941 r. decyzją Sztabu Naczelnego utworzona została I Brygada proletariacka pod dowództwem Kosty Popovicia, doborowa jednostka podporządkowana bezpośrednio Josipowi Broz-Tito.

Jednocześnie począł formować się w Serbii ruch zbrojny, podporządkowany królewskiemu rządowi emigracyjnemu. Dowodził nim pułkownik Sztabu Generalnego Dragoljub (Draža) Mihailović, który po kapitulacji Jugosławii z 17 kwietnia uniknął niewoli i nie złożył broni walcząc z Niemcami i ich sojusznikami, w tym także z NDH. Przy pomocy oficerów opowiadających się za wyzwoleniem Królestwa Jugosławii począł organizować oddziały czetnickie, znajdując poparcie wśród polityków o orientacji prozachodniej. Wycofał się do Serbii i już 11 maja 1941 r. doprowadził do utworzenia Dowództwa Oddziałów Czetnickich Wojska Jugosłowiańskiego. Nawiązał on kontakt z rządem emigracyjnym, uzyskując awans na stopień generała i stanowisko ministra wojny. Organizacja czetnicka rozrosła się niebawem do poważnych rozmiarów i przekształciła się w Jugosłowiańską Armię Krajową, popieraną przez Anglików, traktujących Mihailovicia jako wodza walczącej Jugosławii. Dzięki jego działalności wzmocniona została pozycja rządu emigracyjnego w Londynie ${ }^{14}$.

Powyższe zagadnienia nie zostały omówione w komunikatach rozgłośni im. T. Kościuszki dlatego warto było krótko przedstawić okoliczności agresji niemieckiej na Jugosławię oraz wyjazdu rządu z kraju, który udał się na emigrację. Dla poniższych rozważań ważne jest wyjaśnienie, kiedy powstała partyzantka komunistyczna.

W latach 1942-1943 Rozgłośnia im. T. Kościuszki informowała polskich radiosłuchaczy, m.in. o tym, jakie miasta zostały wyzwolone przez jugosłowiańskich partyzantów. Radio próbowało zlokalizować, w jakich regionach nieistniejącej już Jugosławii znajdowały się wymienione ośrodki miejskie, np. w Chorwacji, Słowenii czy Sandżaku. Niestety autorzy doniesień radiowych stosowali fonetyczny zapis nazw miejscowości, który bardzo utrudniał w wielu przypadkach ustalenie, o jakie miasto chodzi i jak powinno się je prawidłowo zapisywać.

W audycjach wymieniano następujące miasta w porządku chronologicznym: Sarajewo, Višegrad, Tuzla ${ }^{15}$, Nikšsić ${ }^{16}$, Valjevo, Šabac ${ }^{17}$, Cetinje (wyzwolicielami byli

${ }^{14}$ L. Podhorodecki, dz. cyt., s. 169. O Mihailoviciu szerzej patrz: S. Trew, Britain, Mihailović and the Chetniks, Wyd. St. Martin's Press, Londyn 1998; J. Tomasevitch, The Chetniks, Wyd. Stanford University Press, Stanford 1975.

${ }^{15}$ Audycja z 8 lutego 1942 r., Archiwum Akt Nowych [dalej: AAN], Radiostacja „Kościuszko”, sygn. 321, t. 2, k. 246.

${ }^{16}$ Audycja z 4 kwietnia 1942 r., tamże, t. 3, k. 220.

${ }^{17}$ Audycja z 30 kwietnia 1942 r., tamże, t. 4, k. 8. 
płk. Sava Orović i kpt. Peko Dapčevićc ${ }^{18}$, Srebrenica ${ }^{19}$, Kraševo $^{20}$, Prijedor $^{21}$, Prozor $^{22}$, Gornji Vakuf ${ }^{23}$, Brušane w Chorwacji ${ }^{24}$, Tušilović koło Karlovca ${ }^{25}$, Bosanska Krupa, Cazin $^{26}$, miejscowość trudna do zidentyfikowania może Tešanj ${ }^{27}$, Vočin ${ }^{28}$, Imotski (Peko Dapčević) $^{29}$, [Bosanski - A.K.] Petrovac, Drvar ${ }^{30}$, Nevesinje $^{31}$ (Hercegowina), Kalinovik $^{32}$, Gračac ${ }^{33}$, Ključ ${ }^{34}$, Crikvenica, Kraljevica, Senj, Sušak [obecnie dzielnica Rijeki - A.K.], Obrovac, Klis, Kaštel (Dalmacja), Črnomelj, Kočevje, Grosuplje (Słowenia) $^{35}$, Split ${ }^{36}$, Ulcinj, Petrovac ${ }^{37}$, Pljevlja - tu wymieniana błędnie jako stolica Sandżaku ${ }^{38}$, Kolašin (Czarnogóra), Tuzla ${ }^{39}$, Berane (Czarnogóra) ${ }^{40}$, Zenica ${ }^{41}$, Posušje (Dalmacja) ${ }^{42}$, Nova-Varoš (Sandżak) - wyzwolone przez 2 Korpus dowodzony przez gen. Peko Dapčevicia ${ }^{43}$, Bileća (Hercegowina) - oswobodzona przez oddziały 10. brygady $^{44}$, Bosanska Dubica ${ }^{45}$, Vareš Majdan (ośrodek przemysłowy w Bośni wyzwolony przez płk. Gliga vel Bliga Mandicia), Bistrica ${ }^{46}$, Andrijevica (Czarnogóra),

\footnotetext{
18 Audycja z 15 czerwca 1942 r., tamże, k. 413.

${ }^{19}$ Audycja z 18 lipca 1942 r. tamże, t. 5, k. 283.

${ }^{20}$ Audycje z 25 lipca 1942 r., tamże, k. 391.

21 Audycje z 23, 25 lipca 1942 r., tamże, k. 349, 391.

22 Audycje z 25 lipca 1942 r., 3, 7 marca 1943 r., tamże, t. 5, k. 390; t. 13, k. 34, 106.

23 Audycja z 25 lipca 1942 r., tamże, t. 5, k. 390.

24 Audycje z 12, 15 listopada 1942 r., tamże, t. 9, k. 193-194, 245.

25 Audycja z 12 listopada 1942 r., tamże, k. 193-194.

26 Audycja z 26 listopada 1942 r., tamże, k. 410.

27 Audycja z 18 stycznia 1943 r., tamże, t. 11, k. 270.

28 Audycja z 10 lutego 1943 r., tamże, t.12, k. 141.

29 Audycja z 24 lutego 1943 r., tamże, k. 315.

30 Audycja z 27 marca 1943 r., tamże, t. 13, k. 390

31 Audycje z 2, 3 kwietnia 1943 r., tamże, t. 14, k. 28,35.

32 Audycja z 2 kwietnia 1943 r., tamże, k. 28.

33 Audycja z 3 kwietnia 1943 r., tamże, k. 35.

34 Audycja z 13 sierpnia 1943 r., tamże, t. 17, k. 212.

35 Audycja z 17 września 1943 r., tamże, t. 18, k. 264.

36 Audycja z 23 września 1943 r., tamże, k. 351.

37 Audycja z 25 września 1943 r., tamże, k. 380.

38 Audycja z 30 września 1943 r., tamże, k. 450.

39 Audycja z 7 października 1943 r., tamże, t. 19, k. 82.

40 Audycja z 15 października 1943 r., tamże, k. 227.

41 Audycje z 15, 19, 21 października 1943 r., tamże, k. 227, 298, 324.

42 Audycja z 21 października 1943 r., tamże, k. 324.

43 Audycja z 22 października 1943 r., tamże, t. 19, k. 345. Przypuszczam, że była mowa o 2. Korpusie Bośniackim utworzonym 11 maja 1943 r. w składzie 4., 10., 11. dywizje (do 10 sierpnia 1943 r.). Rozkazem Sztabu Naczelnego z 5 października 1943 r. otrzymał nazwę 5. Korpusu Bośniackiego. Szerzej: V. Strugar, Wojna i rewolucja narodów Jugostawii 1941-1945, Wyd. M.O.N., Warszawa 1967, s. 451.

44 Audycja z 22 października 1943 r., AAN, Radiostacja..., t. 19, k. 345. Najprawdopodobniej chodzi o 10. Hercegowińską Brygadę utworzoną 10 sierpnia 1942 r. Patrz: V. Strugar, dz. cyt., s. 429.

45 Audycja z 23 października 1943 r., AAN, Radiostacja...., t. 19, k. 371.

46 Audycja z 2 listopada 1943 r., tamże, t. 20, k. 27-29.
} 
Kičevo (Macedonia) ${ }^{47}$, Koprivnica, Virovitica (Slavonia) - miasta położone blisko granicy z Węgrami ${ }^{48}$, Kobarid i Tolmin w Słowenii ${ }^{49}$.

Stacja informowała wokół jakich miast i na jakim obszarze Jugosławii były prowadzone walki, które wiązały siły nieprzyjaciela. Wymieniano miasta: Nikšić, Mo$\operatorname{star}^{50}$, Triest ${ }^{51}$, Novi Sad i dolinę Dunaju ${ }^{52}$, Banja Lukę $e^{53}$, Maribor, Ljubljanę ${ }^{54}$, Mrkonjić-Grad, Ključ 55 , Kordun, Perjasicę ${ }^{56}$, Gračac, Gospić, Slunj, Glina, Bosanski Novi, Sanski Most, Prijedor ${ }^{57}, \operatorname{Knin}^{58}$, Bileća ${ }^{59}$, Foča ${ }^{60}$, Ostrica, Lepoglava ${ }^{61}$, Split, Livno, Goražde, Kalinovik ${ }^{62}$, rzekę Sitnica ${ }^{63}$, terytoria Czarnogóry ${ }^{64}$, Sandżaku i Hercegowiny ${ }^{65}$.

We wrześniu 1943 r. radio informowało, że obszar między Kolnicą a Mostarem (Bośnia i Hercegowina) ${ }^{66}$ oraz fragment wybrzeża chorwackiego od Sušaku do Senja) zostały oswobodzone spod okupacji państw Osi ${ }^{67}$. Stacja wspominała również o tym, że w „rękach” partyzantów znalazły się wyspy: Brač, Hvar i Vis ${ }^{68}$. Północna Chorwacja ${ }^{69}$ jeszcze w lutym 1943 r. miała cieszyć się wolnością. Tylko w nielicznych zapisach audycji znajdują się informacje, kto dokonał wyparcia przeciwnika z jugosłowiańskich miast, jaka to była partyzantka, jaka to była jednostka i kto nią dowodził.

Czasami można odnieść wrażenie, że radio celowo bardzo enigmatycznie określało, kto przeprowadzał udane akcje, i przeciw komu były one skierowane. Autorzy doniesień stwierdzali, że byli to żołnierze: „partyzanckiej armii Jugosławii”"70, ,par-

47 Audycja z 12 listopada 1943 r., tamże, k. 186.

48 Audycja z 17 listopada 1943 r., tamże, k. 263.

49 Audycja z 27 listopada 1943 r., tamże, k. 439.

${ }^{50}$ Audycja z 15 czerwca 1942 r., tamże, t. 4, k. 412.

${ }^{51}$ Audycja z 11 lipca 1942 r., tamże, t. 5, k. 184.

52 Audycja z 21 lipca 1942 r., tamże, k. 325.

${ }^{53}$ Audycja z 25 września, 20 października 1942 r., tamże, t. 7, k. 375; t. 8, k. 327.

54 Audycja z 25 września 1942 r., tamże, t. 7, k. 376 i audycja z 28 września 1943 r., tamże, t. 18, k. 425 .

${ }^{55}$ Audycja z 20 października 1942 r., tamże, t. 8, k. 327.

56 Audycja z 5 listopada 1942 r., tamże, t. 9, k. 80.

${ }^{57}$ Audycja z 9 lutego 1943 r., tamże, t. 12, k. 129. Na temat działań militarnych w rejonie Sanski Most-Klucz patrz: audycja z 19 lutego 1943 r., tamże, t. 12, k. 248.

${ }^{58}$ Audycja z 14 kwietnia 1943 r. tamże, t. 14, k. 184.

${ }^{59}$ Audycja z 10 maja 1943 r., tamże, k. 544.

${ }^{60}$ Audycja z 7 czerwca 1943 r., tamże, t. 15, k. 88.

${ }^{61}$ Audycja z 22 sierpnia 1943 r., tamże, t. 17, k. 357.

${ }^{62}$ Audycja z 26 kwietnia 1944 r., tamże, t. 25, k. 366.

${ }^{63}$ Audycja z 14 września 1942 r., tamże, t.7, k. 208.

${ }^{64}$ Audycje z 20, 27, 29 czerwca 1943 r., tamże, t. 15, k. 287, 386, 411.

${ }^{65}$ Audycje z 20, 29 czerwca 1943 r., tamże, k. 287, 411.

${ }^{66}$ Audycja z 21 lipca 1942 r., tamże, t. 5, k. 325.

${ }^{67}$ Audycja z 16 września 1943 r., tamże, t. 18, k. 237.

${ }^{68}$ Audycja z 17 września 1943 r., tamże, k. 264.

${ }^{69}$ Audycja z 27 lutego 1943 r., tamże, t. 12, k. 362.

${ }^{70}$ Audycja z 14 września 1942 r., tamże, t. 7, k. 208. 
tyzancko-ochotniczej armii w Jugosławii" ${ }^{71}$, ,jugosłowiańscy partyzanci”72, by ostatecznie używać terminu „Jugosłowiańska Armia Narodowowyzwoleńcza”73.

Na podstawie zapisu audycji można stwierdzić, że stacja omawiała jedynie dokonania komunistycznego ruchu oporu. Ruch ten w latach 1941-1942 przeszedł ewolucję organizacyjną. Powołany w dniu 27 czerwca 1941 r. na posiedzeniu Komitetu Centralnego przez Komitet Centralny Komunistycznej Partii Jugosławii Sztab Główny Narodowowyzwoleńczych Oddziałów Partyzanckich Jugosławii (NOPOJ) pod koniec stycznia 1942 r. przemianowano go przemianowany został na Sztab Naczelny Narodowowyzwoleńczych Oddziałów Partyzanckich i Ochotniczego Wojska Jugosławii (NOP i DVJ). W związku z formowaniem pierwszych dywizji i korpusów - w listopadzie 1942 r. przemianowano go na Sztab Naczelny Wojska Narodowowyzwoleńczego i Oddziałów Partyzanckich Jugosławii (NOV i POJ) ${ }^{74}$. Wydawał on liczne komunikaty, które były jednym z głównych źródeł informacji dla rozgłośni Kościuszko ${ }^{75}$.

Pracownicy stacji czerpali również wiadomości z doniesień innego radia, mianowicie rzekomo partyzanckiego radia „Wolna Jugosławia” (Slobodna Jugoslavija). Rozgłośnia ta nie mieściła się jednak na obszarze dawnej Jugosławii, lecz została powołana do życia przez Międzynarodówkę Komunistyczną i przez okres II wojny światowej funkcjonowała na terytorium ZSRR. Pełniła więc funkcję podobną, jak rozgłośnia Kościuszko i nie mogła mieć informacji z pierwszej ręki.

Godne analizy jest to, czy w powyższych audycjach zostały zawarte prawdziwe informacje dotyczące zajmowania miast, które znajdowały się na terytorium NDH, czy Królestwa Czarnogóry pod protektoratem włoskim. Dla przykładu wykorzystam przekaz z 4 kwietnia 1942 r. w którym stwierdzono, że 5 marca wyzwolono miasto Nikšić ${ }^{76}$ w Czarnogórze. W latach 1941-1943 nie było ono kontrolowane przez jugosłowiańskich partyzantów, jednocześnie mogło znajdować się w ich posiadaniu przez krótki okres czasu. W doniesieniu radiowym z 23 lipca 1942 r. oznajmiono, że został opanowany Prijedor ${ }^{77}$, z czym należy się zgodzić, nastąpiło to w nocy z 15 na 16 maja $1942 \mathrm{r}^{78}$

Nie było najważniejsze, podawanie dokładnych informacji jak i kiedy zdobywano poszczególne miasta. Chciano polskim odbiorcom tychże treści uświadomić jedną istotną rzecz, mianowicie w Jugosławii odległej od granic Polski, funkcjonują oddziały, które skutecznie stawiają zbrojny opór siłom państw Osi. Są one na tyle waleczne, że potrafią zdobyć ośrodki miejskie, przemysłowe oraz miasteczka i wsie. Pracownicy

${ }^{71}$ Audycja z 12 listopada 1942 r., tamże, t. 9, k. 193.

72 Audycja z 28 lutego 1943 r., tamże, t. 12, k. 365.

73 Audycje z 23 maja, 20 czerwca, 13 sierpnia, 16, 28 września, 7 października 1943 r., tamże, t. 14, k. 763 ; t. 15 , k. 287 ; t. 17 , k. 212 ; t. 18 , k. 237,425 ; t. 19 , k. 82 .

${ }^{74}$ V. Strugar, dz. cyt., s. 381.

75 Audycje z 10, 16 maja 1943 r., AAN, Radiostacja..., t. 14, k. 544, 636.

${ }^{76}$ Audycja z 4 kwietnia 1942 r., tamże, t. 3, k. 220.

77 Audycje z 23, 25 lipca 1942 r., tamże, t. 5, k. 349, 391.

${ }^{78}$ V. Strugar, dz. cyt., s. 93. 
radia chcieli nakłonić słuchaczy do wzorowania się na doświadczeniach jugosłowiańskich. Polacy mieli organizować ruch oporu, który będzie prowadził na szeroką skalę działania militarne podobnie jak miało to wówczas miejsce na Bałkanach. ocenie Należy sądzić takie były intencje pracowników redakcji polskojęzycznej rozgłośni.

Stacja informowała wokół jakich miast i na obszarze jakich krain historycznych Jugosławii były prowadzone walki, które wiązały siły nieprzyjaciela. Wymieniano Nikšić, Mostar ${ }^{79}$, Triest ${ }^{80}$, Novi Sad i dolinę Dunaju ${ }^{81}$, rzekę Sitnica ${ }^{82}$, miasta Banja Luka $^{83}$, Maribor, Ljubljana ${ }^{84}$, Mrkonjić-Grad, Ključ ${ }^{85}$, Kordun, Perjasica ${ }^{86}$, Gračac, Gospić, Slunj, Glina, Bosanski Novi, Sanski Most, Prijedor ${ }^{87}$, Knin $^{88}$, Bileća ${ }^{89}$, Foča ${ }^{90}$, Czarnogóra $^{91}$, Sandżak, Hercegowina ${ }^{92}$, Ostrica, Lepoglava ${ }^{93}$, Split, Ljubljana ${ }^{94}$, Livno, Goražde, Kalinovnik ${ }^{95}$.

Po wysłuchaniu powyższych doniesień polski słuchacz miał nabrać przeświadczenia, że Jugosłowianie stworzyli partyzantkę o imponujących rozmiarach, skoro prowadzą walkę na tak rozległych terytoriach: w Bośni i Hercegowinie, Czarnogórze, Chorwacji, Serbii etc. Można było odnieść wrażenie, że cały kraj znajdował się w ogniu bitew i potyczek. Jeżeli więc udało się zorganizować na Bałkanach działalność wyzwoleńczą o tak wielkich rozmiarach, to dlaczego nie może się to powieść w okupowanej Polsce? Nikt jednak nie wspomniał o tym, że przeważającą część terytorium Jugosławii stanowiły góry, niekiedy trudno dostępne. Warunki naturalne bardziej sprzyjały tu rozwojowi oddziałów partyzanckich niż w nizinnej głównie Polsce.

Rozgłośnia, powołując się na doniesienia prasowe (gazeta „Novo Vreme”), podawała przykłady m.in. ataku przeprowadzonego na przedstawicieli lokalnych władz okupacyjnych (niemieckich) w rejonie miasta ${ }^{96}$ Knežica w Bośni oraz na garnizon niemiecki koło miasta Kutina w Chorwacji ${ }^{97}$, który ostatecznie został zniszczony.

\footnotetext{
${ }^{79}$ Audycja z 15 czerwca 1942 r., AAN, tamże, t. 4, k. 412.

80 Audycja z 11 lipca 1942 r., tamże, t. 5, k. 184.

81 Audycja z 21 lipca 1942 r., tamże, k. 325.

82 Audycja z 14 września 1942 r., tamże, t.7, k. 208.

83 Audycja z 25 września, 20 października 1942 r., tamże, t. 7, k. 375; t. 8, k. 327.

84 Audycja z 25 września 1942 r., tamże, t. 7, k. 376.

85 Audycja z 20 października 1942 r., tamże, t. 8, k. 327.

86 Audycja z 5 listopada 1942 r., tamże, t. 9, k. 80.

${ }^{87}$ Audycja z 9 lutego 1943 r., tamże, t. 12, k. 129. Na temat działań militarnych w rejonie Sanski Most-Klucz patrz: audycja z 19 lutego 1943 r., tamże, t. 12, k. 248.

${ }^{88}$ Audycja z 14 kwietnia 1943 r. tamże, t. 14, k. 184.

${ }^{89}$ Audycja z 10 maja 1943 r., tamże, k. 544.

90 Audycja z 7 czerwca 1943 r., tamże, t. 15, k. 88.

91 Audycje z 20, 27, 29 czerwca 1943 r., tamże, k. 287, 386, 411.

92 Audycje z 20, 29 czerwca 1943 r., tamże, k. 287, 411.

93 Audycja z 22 sierpnia 1943 r., tamże, t. 17, k. 357.

94 Audycja z 28 września 1943 r., tamże, t. 18, k. 425.

95 Audycja z 26 kwietnia 1944 r., tamże, t. 25, k. 366

96 Tamże, t. 5, k. 19.

97 Audycja z 20 października 1942 r., tamże, t. 8, k. 327.
} 
Niewątpliwie radio, posługując się przykładami partyzantów z Jugosławii, zachęcało, aby niszczyć aparat represji, który działał na terenie Polski. Takie praktyki utrudniłyby Niemcom sprawowanie władzy. Można dostrzec pewne podobieństwo, treści komunikatów dotyczących działań w Jugosławii z tymi, które przedstawiały działalność Gwardii Ludowej w Polsce. W tym wypadku również informowano przede wszystkim o tym, jak GL likwiduje niemieckich starostów, szefów SS etc. Można więc te informacje potraktować jako swoisty instruktaż.

Temu celowi służyły zapewne również informacje na temat akcji przeprowadzanych przez jugosłowiańskich partyzantów, których celem była dezorganizacja niemieckiej kolei. W komunikatach podawano na jakich trasach dochodziło do wykolejenia pociągów, walk oraz zniszczenia dworców kolejowych. Wspominano tu o działaniach prowadzonych na szlakach: Belgrad-Niš ${ }^{98}$, Konjic, leżącej na trasie MostarSarajevo $^{99}$, Sofia-Skopje ${ }^{100}$, Mostar-Sarajewo ${ }^{101}$, Triest-Lublana ${ }^{102}$, Ogulino-Split (walki z Włochami) ${ }^{103}$, Sisak-Zagrzeb ${ }^{104}$, Brod-Zagrzeb, Sisak-Sunja ${ }^{105}$, BelgradSarajewo (51 stacji kolejowych zniszczonych przez partyzantów) ${ }^{106}$, Lublana-Triest ${ }^{107}$, Travnik-Vites (na tej linii zniszczono pociąg) ${ }^{108}$, Prijedor-Bosanski Novi ${ }^{109}$, BelgradZagrzeb $^{110}$.

Powyższe informacje miały zachęcić polskich słuchaczy do odważnych przedsięwzięć, których celem było sparaliżowanie linii komunikacyjnych. Jak wiadomo, służyły one do przewożenia broni, amunicji, żołnierzy etc. Warto zwrócić uwagę na czas, w którym nadawano omawiane tu komunikaty. Było to wiosną, latem i jesienią 1942 r., Podobne treści podawano również w 1943 r. Wiązało się to z wydarzeniami, jakie miały miejsce na Bałkanach. W latach 1942-1943 partyzantka komunistyczna wykazywała się wzmożoną aktywnością. Jugosławia była najlepszym przykładem, jak należało prowadzić walkę narodowowyzwoleńczą, która mogłaby odciągnąć duże siły niemieckie od głównego teatru działań wojennych Nie zostałyby one dzięki temu wykorzystane na froncie wschodnim przeciwko Armii Czerwonej.

Stacja często posługiwała się liczbami, które odzwierciedlały dokonania partyzantów jugosłowiańskich. W przekazach z 18 lipca 1942 r. stwierdzono, że na 52 powiaty Bośni i Hercegowiny 36 znalazło pod kontrolą partyzantów (radio nie pre-

\footnotetext{
98 Audycja z 4 kwietnia 1942 r., tamże, t. 3, k. 220.

99 Audycja z 21 lipca 1942 r., tamże, t. 5, k. 325.

100 Audycja z 21 lipca 1942 r., tamże, k. 325.

101 Audycja z 23 lipca 1942 r., tamże, k. 349.

102 Audycja z 3 września 1942 r., tamże, t. 7, k. 39.

103 Audycja z 25 września 1942 r., tamże, k. 375.

104 Audycja z 11 października 1942 r., tamże, t. 8, k. 174.

105 Audycja z 20 października 1942 r., tamże, k. 328.

106 Audycja z 27 marca 1943 r., tamże, t. 13, k. 390.

107 Audycja z 31 sierpnia 1943 r., tamże, t. 17, k. 470.

108 Audycja z 9 października 1943 r., tamże, t. 19, k. 146.

109 Audycja z 30 listopada 1943 r., tamże, t. 20, k. 489.

110 Audycja z 24 grudnia 1943 r., tamże, t. 21, k. 403, 404.
} 
cyzowało, kto tego dokonał lakonicznie podając, że partyzanci jugosłowiańscy) ${ }^{111}$. W innym, nadanym 28 stycznia 1943 r., komunikacie podano, że 50 tys. km kw. ${ }^{112}$ zostało wyzwolonych spod okupacji państw Osi, co mogło być bliskie prawdy ${ }^{113}$. Nie wiadomo, jaki obszar byłej Jugosławii mieli na myśli autorzy tego przekazu. Z innego doniesienia (z 3 marca 1944 r.) wynikało, że armie marszałka Tity oswobodziły $80 \%$ obszaru Bośni środkowej ${ }^{114}$. Tylko w jednej audycji wskazano, że autorem powyższych sukcesów, które zaowocowały wyparciem wroga z dużej części Bośni i Hercegowiny były siły komunistyczne.

Radio odwoływało się do wyższych uczuć, propagowało patriotyzm i poświęcenie życia dla kraju. Przykładem tego może być historia starszej kobiety, Słowenki z Bari koło Rybnicy - Marii Ivančić. Przedstawiano ją na antenie stacji jako wzór matki i patriotki, gdyż oddała ojczyźnie swoich synów, aby walczyli o niepodległość dla Jugosławii. Niestety, jej dzieci poległy na polu walki ${ }^{115}$.

Wielokroć informowano o stratach ponoszonych przez wojska państw Osi. Stwierdzono np., że „w ciągu trzech miesięcy partyzanci wycięli w Bośni, Chorwacji, Słowenii 30 tysięcy wojsk okupacyjnych”116. W innym przekazie podano: „W ciągu 35 dni walk tysiące Niemców zginęło koło miasta Konjic, Prozor, Gornji Vakuf"117. Przytoczone wiadomości również uzmysławiały słuchaczom, na jaką skalę były prowadzone walki w Jugosławii, skoro tak wielu żołnierzy III Rzeszy utraciło życie.

$\mathrm{W}$ wiadomościach radiowych oznajmiano słuchaczom, ile sprzętu wojskowego zdobyli Jugosłowianie: 4 tys. karabinów, 300 tys. nabojów, ponad 5 tys. granatów ${ }^{118}$. To również świadczyło o skuteczności i sile partyzantów z Bałkanów. Niestety nie wspomniano, kiedy zagarnięto wspomnianą broń.

Rozgłośnia wskazywała na słabość włoskich jednostek militarnych, które znajdowały się w Jugosławii. Przykładowo podano, że dwa bataliony dywizji Venezia, które stacjonowały w mieście Bioča niedaleko Podgoricy (Czarnogóra), zostały doszczętnie zniszczone przez oddziały Tity ${ }^{119}$. Wspominano o przypadkach rozbrajania całych dywizji - Bergamo, Mugre ${ }^{120}$, które walczyły u wybrzeży Morza Adriatyckiego. Przy zajęciu czarnogórskiej miejscowości Kolašin Włosi oddali swój sprzęt wojskowy stronie partyzanckiej ${ }^{121}$. Po wyzwoleniu miejscowości Berane cała dywizja Venezia

111 Audycja z 18 lipca 1942 r. tamże, t. 5, k. 283.

112 Audycja z 28 stycznia 1943 r., tamże, t. 11, k, 417. Wspomina o tym L. Podhorodecki, dz. cyt., s. 171 .

113 W. Felczak, T. Wasilewski, Historia Jugosławii, Wyd. Zakład Narodowy im. Ossolińskich, Wrocław-Warszawa-Kraków 1985, s. 489.

114 Audycja z 3 marca 1944 r., AAN, Radiostacja..., t. 24, k. 45.

115 Audycja z 14 kwietnia 1944 r., tamże, t. 25, k. 198.

116 Audycja z 28 stycznia 1943 r., tamże, t. 11, k, 417.

117 Audycja z 4 kwietnia 1943 r., tamże, t. 14, k. 55.

118 Audycja z 4 maja 1943 r., tamże, t. 14, k. 453.

119 Audycja z 26 maja 1943 r., tamże, k. 763.

120 Audycja z 23 września 1943 r., tamże, t. 18, k. 351.

121 Audycje z 7 października 1943 r., tamże, k. 82. 
przeszła na stronę jugosłowiańską ${ }^{122}$. Wydarzenie to istotnie miało miejsce 10 października $1943 \mathrm{r}^{123}$. Wszystko to miało potwierdzać tezę, że wśród żołnierzy państw Osi brakuje ducha walki, i że powoli, ale konsekwentnie szala zwycięstwa przechyla się na stronę partyzantów.

Polscy radiosłuchacze mogli dowiedzieć się o przeprowadzanych akcjach sabotażowych w przemyśle działającym na potrzeby niemieckiej machiny wojennej. Informowano, że w mieście Zenica zostały zniszczone zakłady Kruppa produkujące broń ${ }^{124}$ oraz że wysadzono w powietrze kopalnię rtęci w Indriji (Słowenia), która pod względem wydobycia tego minerału zajmowała drugie miejsce w Europie ${ }^{125}$. Wspominano m.in. o zniszczonych obiektach takich, jak elektrownie w Javorniku i Žirovnicy ${ }^{126}$, czy o przerwaniu kabla wysokiego napięcia, który dostarczał prąd do fabryk zbrojeniowych położonych w Trieście ${ }^{127}$.

Być może spodziewano się, że polscy robotnicy pracujący w zakładach, które działały dla niemieckiego wojska, przyjmą taką samą postawę, jaką prezentowali partyzanci jugosłowiańscy. Autorzy doniesień podawali wiele przykładów, które mogły służyć Polakom jako wzór do naśladowania. W dwóch komunikatach wspomniano o uwolnieniu więźniów znajdujących się w więzieniu w Karlovcu ${ }^{128}$ (Chorwacja) oraz o odbiciu angielskich jeńców wojennych, przewożonych w wagonach kolejowych przez Słowenię do Niemiec ${ }^{129}$. Zachęcano słuchaczy, aby nieśli pomoc osobom, które jej potrzebowały i w tym sensie audycje posiadały także wymiar humanitarny.

Omawiano również na antenie postawę jugosłowiańskich chłopów, którzy przestali powiększać areał upraw, z tego względu, że całe zbiory były zabierane przez Niemców. Stosowanie kar przez okupanta wobec rolników, którzy nie dostarczali odpowiedniej ilości zboża, skutkowało tym, że uciekali oni ze swoich rodzinnych wiosek i wstępowali do oddziałów partyzanckich ${ }^{130}$.

W komunikatach stacji podawano, ilu partyzantów walczyło w Wojsku Narodowowyzwoleńczym i Oddziałach Partyzanckich Jugosławii, dowodzonym przez Josipa Broz-Tito. Podawano różne liczby: $200^{131}$, 250 ${ }^{132}$, 300 tys. ${ }^{133}$ żołnierzy. Dwukrotnie, w przekazach z 30 kwietnia i 15 sierpnia 1942 r., pojawiła się liczba 200 tys. żołnierzy. Według innych danych pod koniec 1942 r. komunistyczna partyzantka liczy-

\footnotetext{
122 Audycja z 15 października 1943 r., tamże, t. 19, k. 227.

123 V. Strugar, dz. cyt., s. 470.

124 Audycje z 15, 19 października 1943 r., AAN, Radiostacja..., t. 19, k. 227, 324.

125 Audycja z 18 lutego 1944 r., tamże, t. 22, k. 230.

126 Audycja z 27 lutego 1944 r., tamże, t. 23, k. 370.

127 Audycja z 22 marca 1944 r., tamże, t. 24, k. 325.

128 Audycja z 28 maja 1942 r., tamże, t. 4, k. 240.

129 Audycja z 10 stycznia 1943 r., tamże, t. 11, k. 151.

130 Audycje z 27 marca, 1 czerwca, 7 listopada 1942 r., tamże, t. 3, k. 171; t. 4, k. 284; t. 9, k. 126.

131 Audycje z 30 kwietnia, 15 sierpnia 1942 r., AAN, Radiostacja..., t. 4, k. 8; t. 6, k. 185.

132 Audycje z 23 grudnia 1943 r., 1 stycznia 1944 r., tamże, t. 21, k. 385; t. 22, k. 8.

133 Audycje z 30 marca, 24 maja 1944 r., tamże, t. 24, k. 462; t. 26, k. 368; L. Podhorodecki, dz. cyt., s. 173; W. Walkiewicz, dz. cyt., s. 144; P. Simić, Tito. Zagadka stulecia, Wyd. Dolnośląskie, Wrocław
} 2011, s. 155. 
ła 150 tys. Błąd popełniony przez pracowników rozgłośni mógł wynikać z niewiedzy, przede wszystkim jednak należy pamiętać, że przytaczane dane liczbowe miały charakter szacunkowy. Liczebność partyzantów ulegała zmianie, i to z różnych powodów. Istotne było w tym wszystkim, by pokazać wielkość jugosłowiańskiej armii podziemnej i umiejętność jej stworzenia w takim wymiarze, co powinno skłonić do refleksji polskie grupy konspiracyjne.

Na falach radiowych podawano informacje, które pochodziły z doniesień prasowych, jednoznacznie doceniających wkład jugosłowiańskiej partyzantki kierowanej przez Tito w działaniach na bałkańskim froncie II wojnie światowej. Co ciekawe, przedstawiano także stanowisko czasopism włoskich: „Regime Fasista”134 oraz „Giornale d'Italia”"135, w których stwierdzano, że siły militarne państw Osi nie panują nad sytuacją na Bałkanach. Za niemiecką gazetą „Donau Zeitung ”136. informowano, że włoskie jednostki 7. Dywizji zostały rozbrojone. Donoszono słuchaczom, że Amerykański „New York Times” doceniał męstwo, bohaterstwo i trud dnia codziennego, jaki ponosili żołnierze oddziałów podziemnych ${ }^{137}$, a Czasopisma „Spectator” i „New Statesman ” wyrażały się dobrze o Ticie, jako dowódcy ${ }^{138}$. Tej wybitnej postaci poświęcono wiele miejsca w licznych audycjach. Zamieszczano na przykład wywiady, których udzielił zagranicznym korespondentom agencji Reutera i Associated Press. Dotyczyły one między innymi przygotowań do alianckiego lądowania w Normandii we Francji ${ }^{139}$. Przedstawiano sylwetkę Tity jako człowieka pracowitego, charyzmatycznego, dobrego organizatora w dziedzinie wojskowości ${ }^{140}$. Radio kreowało jego osobę na męża stanu ${ }^{141}$. Na poparcie prezentowanego w audycjach stanowiska posługiwano się opiniami premiera Wielkiej Brytanii Winstona Churchilla ${ }^{142}$ oraz jego syna Randolpha ${ }^{143}$.

Z powyższych komunikatów wynika, że rozgłośnia lansowała pogląd, że Tito był doceniany zarówno przez sojuszników, jak i oponentów. Słowa uznania wypowiedziane przez przywódcę mocarstwa, jakim była Wielka Brytania, miały swoją wymowę. Takie cechy charakteru powinien posiadać przywódca-organizator polskiego ruchu niepodległościowego. Świadczy o tym fragment przekazu radiowego, w którym stwierdzono: „Dla nas, Polaków, którzyśmy przeżyli tragedię września 1939 r. i cztery z górą lata okupacji niemieckiej, bohaterska postawa narodu jugosłowiańskiego jest wzorem tego, jak można prawie gołymi rękami obronić się przed

\footnotetext{
134 Audycja z 24 czerwca 1942 r., AAN, Radiostacja..., t. 4, k. 483.

135 Audycja z 15 lipca 1942 r., tamże, t. 5, k. 217.

136 Audycja z 3 października 1943 r., tamże, t. 19, k. 41.

137 Audycja z 1 stycznia 1944 r., tamże, t. 22, k. 8.

138 Audycja z 15 stycznia 1944 r., tamże, t. 22, k. 232.

139 Audycja z 18 maja 1944 r., tamże, t. 26, k. 272.

140 Audycja z 19 maja 1944 r., tamże, k. 274.

141 Audycja z 24 czerwca 1944 r., tamże, t. 27, k. 387.

142 Audycja z 25 lutego 1944 r., tamże, t. 23, k. 330.

143 Audycja z 16 czerwca 1944 r., tamże, t. 27, k. 254.
} 
nawałą hitlerowską, jak należy organizować skuteczny opór wobec bandytów hitlerowskich" ${ }^{144}$.

W audycjach informowano, że jugosłowiańska partyzantka w dużej mierze składa się z młodzieży akademickiej ${ }^{145}$. Jako przykład podano Szumadyjski Oddział Powstańczy dowodzony przez Milana Blagojevicia ${ }^{146}$. Do oddziałów, którymi dowodził Josip Broz-Tito, przystąpiła również rozwiązana przez Niemców organizacja Sokó $t^{147}$. Rozgłośnia udowadniała w komunikatach, że młode pokolenie Jugosłowian jest dobrze zorganizowane, o czym świadczył fakt, że odbyły się Zjazdy Zjednoczonego Związku Antyfaszystowskiej Młodzieży Jugosławii ${ }^{148}$. Pierwszy miał miejsce w Bihaciu (27-29 grudnia 1942 r.) $)^{149}$, a drugi w Drvarze (2-4 maja 1944 r. $)^{150}$. Oba zorganizowano z inicjatywy KC KPJ.

Jednoznacznie namawiano do tego, by młodzież polska szła za przykładem Jugosłowian, o czym świadczą słowa wypowiedziane w audycji z 24 maja 1944 r.: „Niechaj bojowość i jedność młodzieży jugosłowiańskiej, która dzięki ofiarnej walce z najeźdźcą osiągnęła tak wspaniałe rezultaty, posłuży za przykład do naśladowania dla całej naszej młodzieży"151.

W szeregach komunistycznego Wojska Narodowowyzwoleńczego i Oddziałów Partyzanckich Jugosławii znajdowali się również lekarze ${ }^{152}$, intelektualiści (pisarze, artyści), publicyści ${ }^{153}$, chłopi, robotnicy ${ }^{154}$. Poza ludźmi wykonującymi określone zawody, w armii partyzanckiej były osoby o określonych poglądach politycznych, m.in. chrześcijańscy demokraci, komuniści, socjaliści ${ }^{155}$ etc. To oznaczało, że do zaplecza militarnego Tity mógł wstąpić każdy, kto sprzeciwiał się obecności okupantów na terenie Jugosławii.

144 Audycja z 30 marca 1944 r., tamże, t. 24, k. 463.

145 Audycje z 14 lutego, 17 listopada 1942 r., tamże, t. 2, k. 285; t. 9, k. 268.

146 Audycja z 9 kwietnia 1942 r., tamże, t. 3, k. 255. 1 Szumadyjski - formowanie jego ukończono 1 VII 1941 r. Jego główne siły weszły 21 XII w skład 1. Brygady Proletariackiej. Na początku lipca 1942 r. został utworzony nowy oddział pod nazwą „Milan Blagojević”. Oddał on swój skład osobowy dla formowania 1. Batalionu Szumadyjskiego oraz 1. i 2. Brygady Szumadyjskiej. Od 21 XII 1943 r. do 12 II 1944 r. pozostawał w składzie Tymczasowej Brygady Szumadyjskiej, jako jej 1 batalion. Następnie oddział ten działał września 1944 r., gdy jego ludzie weszli w skład jednostek 1. Korpusu Proletariackiego.

147 Audycje z 23 października 1942 r., 27 sierpnia 1943 r., AAN, Radiostacja..., t. 8, k. 369; t. 17, k. 414.

148 Audycje z 15 stycznia 1943 r., 24 maja 1944 r., tamże, t. 11, k. 216; t. 26, k. 351-352. Radio w komunikacie z 21 stycznia 1944 r. zapowiadało, że w niedługim czasie odbędzie się Zjazd Zjednoczonego Związku Antyfaszystowskiej Młodzieży Jugosławii - patrz: tamże, t. 22, k. 324. Z kolei w doniesieniu z 27 kwietnia 1944 r. stwierdzono, że II Zjazd wówczas trwał, z czym nie należy się zgodzić. Na ten temat: audycja z 27 kwietnia 1944 r., tamże, t. 25, k. 395.

149 V. Strugar, dz. cyt., s. 143.

150 Tamże, s. 242.

151 Audycja z 24 maja 1944 r., AAN, Radiostacja..., t. 26, k. 352.

152 Audycje z 15 października 1942 r., 21 grudnia 1943 r., tamże, t. 8, k. 232; t. 21, k. 336.

153 Audycje z 19 maja, 28 października 1943 r., tamże, t. 14, k. 664; t. 19, k. 446.

154 Audycje z 15 sierpnia 1942r., 6 czerwca 1943 r., tamże, t. 6, k. 185; t. 15, k. 80.

155 Audycja z 27 sierpnia 1943 r. tamże, t. 17, k. 414. 
W kilku audycjach stacja poświęciła uwagę Zgromadzeniu Narodowemu, które odbyło się w Bihaciu w dniach 26-27 listopada 1942 r. Podkreślano w komunikatach, że Wojsko Narodowowyzwoleńcze i Oddziały Partyzanckie Jugosławii skupiają w swoich szeregach Serbów, Chorwatów, Słoweńców i wszystkie wymienione narody zjednoczyły się w walce przeciwko faszystom ${ }^{156}$. Informowano, że powstał Komitet Wykonawczy, któremu przewodzi dr Ivo Lola Ribar. Ten nowy organ gromadził przedstawicieli różnych grup zawodowych (robotników, księży, chłopów, inteligentów) i politycznych (demokraci) ${ }^{157}$. Radio początkowo nie podało że została zorganizowana Antyfaszystowska Rada Wyzwolenia Narodowego Jugosławii (AVNOJ). Dopiero w przekazie z 19 października stwierdzono, że funkcjonuje Antyfaszystowska Rada (Antifašističko Veće), która, według opinii radia londyńskiego, nie była zdominowana przez komunistów ${ }^{158}$. Nie była to prawda, ponieważ powstała ona z inicjatywy KPJ.

O wiele więcej mówiono na temat powstałego Narodowego Komitetu Wyzwolenia Jugosławii (NKOJ), pełniącego rolę rządu. Organ ten powołano na II Sesji AVNOJ w Jajce w nocy 29 na 30 listopada 1943 r. Stacja tłumaczyła, że była to „logiczna konsekwencja walki narodowowyzwoleńczej prowadzonej przez całe społeczeństwo, wszystkie narody Jugosławii, które, bez względu na różnice poglądów politycznych, zwarły swoje siły w jednolitym froncie narodowym" ${ }^{159}$. Podnosi się w tym doniesieniu ideę jedności, solidarności ponad istniejące różnice w kwestii światopoglądowej. Pozostałe komunikaty również były poświęcone temu zagadnieniu w kontekście powołania do życia nowego ośrodka władzy w okupowanej Jugosławii ${ }^{160}$.

Na II Sesji AVNOJ uchwalono deklarację, w której znajdował się punkt dotyczący przyszłego ustroju Jugosławii. Kraj ten miał być federacją, w której nastąpi całkowite równouprawnienie narodów Serbii, Chorwacji, Słowenii, Macedonii, Czarnogóry, Bośni i Hercegowiny. Powyższa kwestia była analizowana w wiadomościach radiowych nadanych 16 grudnia 1943 r. ${ }^{161}$ Podkreślano, że AVNOJ była organem ustawodawczym skupiającym postępowe środowiska, a Narodowy Komitet Wyzwolenia Jugosławii - według radiostacji - cieszył się poparciem wszystkich nacji zamieszkujących obszar wyzwolony przez partyzantkę Tity ${ }^{162}$. Społeczna akceptacja dla komu-

156 Audycja z 4 stycznia 1943 r., tamże, t. 11, k. 57.

157 Audycje z 15 stycznia, 5 marca 1943 r., tamże, t. 11, k. 229; t. 13, k. 83.

158 Audycja z 19 października 1943 r., tamże, t. 19, k. 291. Na temat powołania do życia AVNOJ patrz: J. Woydyłło, Tito jakiego nie znamy, Wyd. Spar, Warszawa 1991, s. 62; W. Walkiewicz, dz. cyt., s. 140; L. Podhorodecki, dz. cyt., s. 172; A. Giza, J. Gmitruk, Tajne raporty z Jugosławii, Wyd. Ludowa Spółdzielnia Wydawnicza, Warszawa 2002, s. 78. M. J. Zacharias, Komunizm, federacja, nacjonalizm. System władzy w Jugosławii 1943-1991.Powstanie, przekształcenie, rozkład, Wyd. Neriton, Warszawa 2004, s. 51.

159 Audycja z 2 grudnia 1943 r., AAN, Radiostacja..., t. 21, k. 20.

160 Audycje z 10, 12 grudnia 1943 r., 12 lutego, 4 marca 1944 r. tamże, t. 21, k. 168, 199; t. 23, k. 146; t. 24, k. 60 .

161 Audycja z 16 grudnia 1943 r., tamże, t. 21, k. 259. O tym, co uchwalono na II Sesji AVNOJ jesienią 1943 r. pisze E. Mizerski, Jugosłowiański system przedstawicielski 1918-1990 (w zarysie), Wyd. Adam Marszałek, Toruń 1999, s. 59-60.

162 Audycje z 19, 20, 22 stycznia 1944 r., AAN, Radiostacja..., t. 22, k. 280, 297, 336. 
nistów wynikała głównie z faktu, że dobrze zorganizowali oni życie mieszkańców tych obszarów, które znalazły się pod ich jurysdykcją. Według radia, rząd ten posiadał własne banki, drukował pieniądze, udzielał pożyczek, zarządzał koleją i pocztą, krzewił rozwój kultury oraz wydawał setki niewielkich gazet ${ }^{163}$. Nastąpił rozwój administracji terytorialnej, który, według opinii rozgłośni, przedstawiał się następująco: „Na czele każdej wsi stoją Komitety wiejskie, następnie idą Komitety powiatowe, a najwyższym organem jest antyfaszystowskie Wecze [Antyfaszystowska Rada Wyzwolenia Narodowego Jugosławii], która wybiera rząd"164.

W ten sposób radio realizowało wytyczne zawarte w uchwale Sekretariatu KW MK z 13 sierpnia 1942 r. Nakazywały one, aby audycje kładły m.in. nacisk na problemy skonsolidowania wszystkich sił antyfaszystowskich w ojczyźnianych, narodowych lub antyhitlerowskich frontach ${ }^{165}$. Przykład jugosłowiański miał służyć Polakom za wzór, który powinien zostać zaadaptowany w okupowanym kraju. Na potwierdzenie swoich słów posłużę się fragmentem audycji: „My, Polacy, przyjmujemy powstanie Tymczasowej władzy wykonawczej w Jugosławii ze zrozumieniem i sympatią, jako dalszy poważny wkład w dzieło walki z hitleryzmem, jako krok, który pozwoli Jugosławii jeszcze bardziej rozszerzyć walkę z hitleryzmem, jeszcze pewniejszym krokiem zdążyć ku swemu wyzwoleniu, jako pierwszy krok do utworzenia w Jugosławii władzy szczerze demokratycznej, stającej na straży interesów narodu"166.

Pomimo że funkcjonował na emigracji konstytucyjny rząd jugosłowiański, podlegający królowi Piotrowi II, radio lansowało pogląd, iż Wielka Brytania ${ }^{167}$, Stany Zjednoczone i ZSRR ${ }^{168}$ przyjęly przychylnie fakt utworzenia „władzy ludowej”. $\mathrm{Z}$ tym nie należy się zgodzić, ponieważ np. dyplomacja angielska podjęła się wielu działań, aby oba ośrodki do siebie zbliżyć po to, by powstał nowy, koalicyjny gabinet. Ujmując rzecz bardzo lakonicznie, autorzy doniesień chcieli w ten sposób uświadomić słuchaczom, że takie działania, jakie zaszły na ziemiach jugosłowiańskich, uzyskują międzynarodową akceptację.

Radio wielokrotnie atakowało Dragoljuba Mihailovicia. Polskojęzyczna stacja w wielu komunikatach przedstawiała jego postać w sposób pejoratywny, oskarżając go o współpracę z Niemcami i Włochami. Sugerowano, że zwalczał grupy narodowowyzwoleńcze podlegające Ticie. Osoba Mihailovicia ${ }^{169}$ stawiana była na równi z ta-

163 Audycja z 1 stycznia 1944 r., tamże, k. 8.

164 Audycja z 17 maja 1944 r., tamże, t. 26, k. 246.

165 Коминтерн и Вторая Мировая война, cz. II, oprac. Н.С Лебедева., М.М. Наринский, Wyd. Памятники исторической мысли, Москва 1998 , s. 249.

${ }^{166}$ Audycja z 2 grudnia 1943 r., AAN, Radiostacja..., t. 21, k. 21.

167 Audycje z 10, 15 grudnia 1943 r., tamże, k. 169, 248.

168 Audycja z 15 grudnia, tamże, k. 248.

169 Audycje z 12 listopada 1942 r., 10, 15 stycznia, 5 marca, 17, 23 września, 22 października, 15, 25, 26, 28 grudnia 1943 r., 3 stycznia, 25 lutego, 4 marca 1944 r., tamże, t. 9, k. 193; t. 11, k. 152, 230; t. 13, k. 83 ; t. 18 , k. 265,351 ; t. 19 , k. 345 ; t. 21 , k. $248,422,436$, 456 ; t. 22 , k. 33 ; t. 23 , k. 330 ; t. 24 , k. 59. 
kimi kolaborantami, jak szef marionetkowego rządu serbskiego - Milan Nedić ${ }^{170}$, czy Ante Pavelićc ${ }^{171}$ (je den $z$ twórców i wódz (poglavnik) faszystowskiego Niezależnego Państwa Chorwackiego i jednocześnie przywódca zbrojnej organizacji ustaszy) ${ }^{172}$. Tym dwóm politykom ostatnim również poświęcono wiele miejsca w audycjach rozgłośni „Kościuszko”, głównie ukazując ich zaangażowanie po stronie państw Osi w prowadzonych działaniach wojennych przeciwko partyzantce komunistycznej na terenie Jugosławii.

Radio, nadając powyższe treści, realizowało wspomniane już wytyczne Sekretariatu KW MK z 10 stycznia 1942 r., które nakazywały, aby na podstawie faktów w przystępnie przedstawionej argumentacji ujawniać fatalne w skutkach przykłady zdrady narodowej rządów, które zdecydowały się na współpracę z nazistowskimi Niemcami, aby osiągnąć ich całkowitą izolację oraz skazać na zgodne potępienie przez narody państw okupowanych ${ }^{173}$. Autorzy doniesień chcieli również wykazać, że tylko komuniści walczą o wyzwolenie swojego kraju tzn. Jugosławii, spod zależności państw faszystowskich.

W związku z tym, że władze sowieckie popierały wówczas Tito, polskojęzyczna stacja radiowa działająca na terenie ZSRR, musiała realizować linię polityczną tego państwa. Pod koniec 1943 r. oraz w 1944 r. nasiliły się nieprzychylne komentarze na temat Mihailovicia, ponieważ w tym czasie dyplomacja brytyjska zmieniła swoje dotychczasowe postępowanie wobec przywódcy czetników. Od listopada 1943 r. Anglicy praktycznie przestali dostarczać pomoc oddziałom czetników. Premier Wielkiej Brytanii Churchill uważał, że należy domagać się od króla Piotra II i premiera emigracyjnego rządu jugosłowiańskiego Božidara Puricia, aby zdymisjonowali Mihajlovicia ze stanowiska ministra wojny ${ }^{174}$. W dniu 8 grudnia w Izbie Gmin minister Stanu Richard Law odpowiadał na pytania deputowanych dotyczące stosunku władz angielskich do NKOJ. Oświadczył on, że rząd angielski wspiera wszystkie siły w Jugosławii, które walczą z Niemcami. Dodał, że partyzanci Tity uzyskują pomoc większą niż oddziały czetników, ponieważ ich wkład do walki z wojskami III Rzeszy jest o wiele większy ${ }^{175}$. Powyższa wypowiedź świadczy, że elity polityczne Wielkiej Brytanii zaczęły przychylniej postrzegać Titę, dystansując się trochę od zajmowanego stanowiska w kwestii rządu jugosłowiańskiego, działającego na emigracji. Fakt ten

170 Audycje z 14 lutego, 4 kwietnia 1942 r., 17, 30 września, 6 grudnia, 23 grudnia 1943 r., 3 stycznia, 4 marca 1944 r., tamże, t. 2, k. 285; t. 3, k. 220; t. 15, k. 80; t. 18, k. 264, 450; t. 21, k. 385; t. 22, k. 33 ; t. 24 , k. 59.

171 Audycje z 11, 30 lipca 1942 r., 10 lutego, 22 sierpnia, 17, 30 września, 23 grudnia 1943 r., 3 stycznia, 4 marca 1944 r., tamże, t. 5, k. 184, 449; t. 12, k. 141; t. 17, k. 357; t. 18, k. 264, 450; t. 21, k. 385; t. 22 , k. 33 ; t. 24 , k. 59.

172 Audycje z 26 września, 20 października, 12, 26 listopada 1942 r., 27 czerwca 1943 r., tamże, t. 7, k. 375; t. 8, k. 327; t. 9, k. 193, 410; t. 15, k. 386.

173 Коминтерн и Вторая..., s. 179.

174 M. J. Zacharias, Jugosławia w polityce Wielkiej Brytanii 1940-1945, Wyd. Zakład Narodowy im. Ossolińskich, Wrocław-Warszawa-Kraków 1985, s. 177.

175 Tamże, s. 178. 
został odnotowany w audycji z 10 grudnia 1943 r. ${ }^{176}$ O tym, że Brytyjczycy oceniali wówczas bardzo chłodno działalność Mihailovicia świadczyła wypowiedź premiera Churchilla w parlamencie 21 lutego 1944 r. ${ }^{177}$ Stwierdził on, że wręcz dochodziło do zawierania układów z Niemcami i Włochami, w których czetnicy zobowiązywali się nie podejmować zbrojnych działań wobec sił Osi. W związku z tym rząd angielski zerwał współpracę z oddziałami, które podlegały formalnie królowi Piotrowi II. Również ta informacja została nadana przez rozgłośnię 25 lutego $1944 \mathrm{r} .{ }^{178} \mathrm{~W}$ tym czasie Winston Churchill zamierzał doprowadzić do tego, aby w nieodległej przyszłości powstał koalicyjny gabinet składający się z komunistów i polityków emigracyjnych. Chodziło głównie o to, by Wielka Brytania nie utraciła swoich wpływów na Półwyspie Bałkańskim.

Początkowo strona sowiecka podzielała punkt widzenia na powyższą kwestię, wyrażając aprobatę dla koncepcji angielskiej, o czym może świadczyć nota nowego ambasadora w Londynie, Fiodora Gusiewa, z 20 grudnia 1943 r. ${ }^{179}$ Jednak prawdziwe stanowisko ZSRR zostało zawarte w komunikacie Biura Informacyjnego Ludowego Komisariatu Spraw Zagranicznych z 14 grudnia. Dokument potępiał działania Mihailovicia, szkodliwe z punktu widzenia walki wyzwoleńczej, z kolei popierał postanowienia II Sesji AVNOJ. Moskwa w ten sposób jasno opowiedziała się po stronie Tity ${ }^{180}$.

Z tych oto powodów radio krytycznie oceniało emigracyjny rząd premiera Puricia, mimo że chciał on podpisać układ o wzajemnej pomocy z ZSRR ${ }^{181}$. Pod koniec grudnia 1943 r. Sowieci odmówili jego zawarcia, ponieważ nie chcieli współpracy dyplomatycznej z gabinetem, w którym znajdował się gen. Mihailović uważany przez nich za faszystę, zajmującego się głównie zwalczaniem komunistycznej partyzantki. W dniu 6 stycznia 1944 r. nadano audycję, w której przedstawiono argumenty, będące podstawą do podjęcia powyższej decyzji ${ }^{182}$.

W pozostałych komunikatach podważano legalność istniejącego rządu emigracyjnego, m.in. przytaczając opinię ambasadora Stanoje Simicia, który pełnił swoją funkcję w Moskwie. Oceniał on, że Purić i jego ministrowie tak naprawdę nikogo nie reprezentują, w przeciwieństwie do NKOJ ${ }^{183}$. Stanowisko dyplomaty zostało przedstawione w audycji z 14 marca 1944 r. ${ }^{184}$

W dniu 19 marca 1944 r. stacja omawiała problem depozytów Narodowego Banku Królestwa Jugosławii. Rzecz dotyczyła dużej sumy pieniędzy w złocie, która znajdowała się w Rio de Janeiro, Ankarze i Londynie. Rozgłośnia próbowała uczy-

\footnotetext{
176 Audycja z 10 grudnia 1943 r., AAN, Radiostacja..., t. 21, k. 169.

177 J. Woydyłł, dz. cyt., s. 97.

178 Audycja z 25 lutego 1944 r., AAN, Radiostacja..., t. 23, k. 330.

179 M. J. Zacharias, Jugostawia ..., s. 182.

180 Tamże, s. 185.

181 Tamże.

182 Audycja z 6 stycznia 1944 r., AAN, Radiostacja..., t. 23, k. 86.

183 M. J. Zacharias, Jugosławia ..., s. 184.

184 Audycja z 14 marca 1944 r., AAN, Radiostacja..., t. 24, k. 203.
} 
nić z Puricia defraudanta, gdyż rozporządzał on tymi środkami finansowymi ${ }^{185}$. Tito próbował mu w tym przeszkodzić i rozesłał do różnych banków zastrzeżenie, że zgromadzone pieniądze państwa jugosłowiańskiego mogą być wykorzystywane tylko przez Narodowy Bank, działający w wyzwolonej Jugosławii. Wskutek tego wezwania Brazylijczycy istotnie zablokowali depozyt w wysokości 11250 tysięcy dolarów ${ }^{186}$. W związku z tym radio podkreślało szczególną dbałość Tity o to, by właściwie rozporządzać publicznymi pieniędzmi.

Starano się natomiast dyskredytować rząd emigracyjny Jugosławii, który otwarcie posądzano o porozumienie $\mathrm{z}$ dowódcami niemieckimi w sprawie współpracy militarnej, wymierzonej przeciwko oddziałom partyzantki „ludowowyzwoleńczej”"187.

Potępiano dwór króla Piotra II za życie w zbytku i luksusie w czasie, gdy w okupowanej Jugosławii bohatersko walczą partyzanci, uniemożliwiając wykorzystanie znacznych sił nieprzyjaciela na Półwyspie Apenińskim ${ }^{188}$. W ten oto sposób radiosłuchacz mógł odnieść wrażenie, że monarcha i jego otoczenie stanowią grono ludzi próżnych, nie dbających o dobro i interes swoich obywateli, znajdujących się w trudnym położeniu.

W kwietniu 1944 r. po długich sporach trzy mocarstwa doszły do porozumienia. Uzgodniły, że rozwiązanie problemu może nastąpić tylko na drodze utworzenia jednolitego rządu na podstawie porozumienia między Narodowym Komitetem Wyzwolenia Jugosławii a rządem emigracyjnym. Churchill jako pierwszy spośród zachodnich aliantów nawiązał kontakt z Josipem Broz-Tito i uzyskał od niego zgodę na rozmowy ze zreorganizowanym rządem emigracyjnym, powstałym w maju 1944 r. pod przewodnictwem dr. Ivana Šubašicia.

W czerwcu 1944 r. premier rządu emigracyjnego przybył na wyspę Vis (przy wybrzeżu chorwackim) i zawarł porozumienie z Tito. W ogłoszonej przez obu polityków deklaracji Šubašić w imieniu rządu emigracyjnego potępił Mihailovicia oraz innych kolaborantów i wezwał narody Jugosławii do skupienia się wokół NKOJ, który ze swej strony zaaprobował współpracę z rządem królewskim i oświadczył, że o ostatecznej formie ustroju państwa jugosłowiańskiego zadecyduje sam naród ${ }^{189}$.

Wiadomości na ten temat zostały przez radio „Kościuszko” podane w dwóch komunikatach - z 12 i 13 lipca 1944 r. Radio, poza prowadzoną przez siebie działalnością informacyjną, zaznaczyło, że w wyniku porozumienia zostały ,zespolone wszystkie siły narodowe Jugosławii - od konserwatystów do skrajnej lewicy - w celu wzmożenia walki z okupantem hitlerowskim" ${ }^{190}$. To oznaczało, że po raz kolejny ra-

185 Audycja z 19 marca 1944 r., tamże, k. 282.

186 J. Woydyłło, dz. cyt., s. 98.

187 Audycje z 12 kwietnia, 6 maja, 6 czerwca 1944 r., AAN, Radiostacja..., t. 25, k. 153; t.26, k. 94; t. 27, k. 90 .

188 Audycja z 28 maja 1944 r., tamże, t. 26, k. 427.

189 L. Podhorodecki, dz. cyt., s. 176. Na ten temat pisze M. J. Zacharias, Komunizm, federacja..., s. 59.

190 Audycja z 12 lipca 1944 r., AAN, Radiostacja..., t. 28, k. 217. Na ten sam temat patrz: audycja z 13 lipca 1944 r., tamże, t. 28, k. 237. 
dio sugerowało, jak powinno się rozwiązywać problemy natury politycznej, zważywszy na to, że okupowana Polska miała wówczas podobny dylemat: kto miał po wojnie sprawować władzę? Celem doniesień była konsolidacja sił w walce wymierzonej przeciwko Niemcom.

Reasumując, komunikaty radiostacji poruszały wiele zagadnień, m.in. wymieniano, jakie miejscowości zostały wyzwolone przez partyzantów spod okupacji państw Osi. Omawiano również temat sabotażu w kolejnictwie i przemyśle, który pracował dla celów militarnych III Rzeszy. Często podawano straty, jakie ponosił nieprzyjaciel (broń, amunicja, żołnierze itd.). Podkreślano niekiedy wprost, że za tymi akcjami stali komuniści, w przeciwieństwie do innych grup partyzanckich (czetnicy), którzy mieli decydować się na współpracę z faszystami. Celem wspomnianych przekazów było krzewienie wśród polskiego społeczeństwa postaw, które zaowocują rozwinięciem ruchu oporu i to na masową skalę. Głównie obowiązek ten spoczywał na młodym pokoleniu.

Poza kwestiami stricte militarnymi łatwo dostrzec, że stacja nie była obojętna wobec wydarzeń politycznych, które miały miejsce w Jugosławii w czasie II wojny światowej. I tym razem stroną scalającą różne środowiska, grupy społeczne - według autorów doniesień radiowych - była lewica rewolucyjna. Posiadała ona program, który będzie realizowany po zakończeniu działań wojennych.

Celem emitowania powyższych treści była chęć mobilizacji Polaków, którzy mieli zjednoczyć się, by wspólnie prowadzić walkę o wolność i niepodległość. Komunistom pozostawiono przywódczą rolę $\mathrm{w}$ tym procesie.

Niemieckie władze okupacyjne po zajęciu Polski przeprowadziły akcję konfiskaty odbiorników radiowych. Po utworzeniu Generalnego Gubernatorstwa za posiadanie i słuchanie radia groził wyrok śmierci. Zatem polskojęzyczna stacja miała ograniczony zasięg, pomimo, iż były prowadzone tajne nasłuchy radiowe przez członków konspiracyjnej PPR oraz AK. Działalność kominternowskiej redakcji nie mogła zachęcić Polaków do stawiania zbrojnego oporu przeciwko Niemcom.

\section{BIBLIOGRAFIA}

Źródła archiwalne

Archiwum Akt Nowych

Radiostacja „Kościuszko”.

Opracowania

Адибеков Г. М., Шахназарова Э. Н., Шириня К. К., Организационная структура Коминтерна. 1919 - 1943, Wyd. РОССПЭН, Москва 1997.

Felczak Wacław, Wasilewski Tadeuszz, Historia Jugosławii, Wyd. Zakład Narodowy im. Ossolińskich, Wrocław-Warszawa-Kraków 1985.

Giza Antoni, Gmitruk Janusz, Tajne raporty z Jugosławii, Wyd. Ludowa Spółdzielnia Wydawnicza, Warszawa 2002 
Коминтерн и Вторая Мировая война, cz. II, oprac. Н.С Лебедева., М.М. Наринский, Wyd. Памятники исторической мысли, Москва 1998.

Kowalski Józef, Rozgłośnia im. Tadeusza Kościuszki (fragment wspomnienia), „Z pola walki” 1961, nr 4

Kozeński Jerzy, Agresja na Jugostawię 1941, Wyd. Instytut Zachodni, Poznań 1979.

Лебедева Н.С., Наринский М.М., Коминтерн и Вторая мировая война (до 22 июня 1941 года), [w:] История Коммунистического интернационала 1919-1943, red. odp. А. О. Чубарьян, Москва 2002.

Mizerski Edmund, Jugostowiański system przedstawicielski 1918-1990 (w zarysie), Wyd. Adam Marszałek, Toruń 1999.

Nazarewicz Ryszard, Komintern a lewica polska. Wybrane problemy, Wyd. Instytut Wydawniczy Książka i Prasa, Warszawa 2008.

Pavlowitch Stevan, Hitler's New Disorder. The Second World War In Yugoslavia, Wyd. Oxford University Press, Londyn 2008.

Podhorodecki Lech, Jugosławia. Dzieje narodów, państw i rozpad federacji, Wyd. Mada, Warszawa 2000

Rawski Tadeusz, Agresja niemiecka przeciwko Grecji i Jugosławii. 27.03.-5.04.1941, „Wojskowy Przegląd Historyczny" 1966, nr 1.

Rawski Tadeusz, Wojna na Bałkanach, Wyd. M.O.N., Warszawa 1981.

Simić Pero, Tito. Zagadka stulecia, Wyd. Dolnośląskie, Wrocław 2011.

Sobór-Świderska Anna, Jakub Berman. Biografia komunisty, Wyd. IPN, Warszawa 2009.

Strugar Vlado, Wojna i rewolucja narodów Jugostawii 1941-1945, Wyd. M.O.N., Warszawa 1967.

Tomasevitch Jozo, The Chetniks, Wyd. Stanford University Press, Stanford 1975.

Trew Simon, Britain, Mihailović and the Chetniks, Wyd. St. Martin's Press, Londyn 1998.

Walkiewicz Wiesław, Jugosławia. Państwa sukcesyjne, Wyd. Trio, Warszawa 2009.

Woydyłł Jerzy, Tito jakiego nie znamy, Wyd. Spar, Warszawa 1991.

Zacharias Michał Jerzy, Jugostawia w polityce Wielkiej Brytanii 1940-1945, Wyd. Zakład Narodowy im. Ossolińskich, Wrocław-Warszawa-Kraków 1985.

Zacharias Michał Jerzy, Komunizm, federacja, nacjonalizm. System władzy w Jugosławii 1943-1991.Powstanie, przekształcenie, rozktad, Wyd. Neriton, Warszawa 2004. 